\title{
Determinants of Fraud Prevention with Spiritual Intelligence as Moderator
}

\author{
SURIANA A.R. MAHDI ${ }^{*}{ }^{*}$, YUSTIANA DJAELANI ${ }^{2}$, SUWITO ${ }^{3}$, IRFANDI BUAMONABOT ${ }^{4}$ \\ ${ }^{1}$ Department of Accounting, KHAIRUN UNIVERSITY, INDONESIA. E-mail: suriana.mahdi@unkhair.ac.id \\ ${ }^{2}$ Department of Accounting, KHAIRUN UNIVERSITY, INDONESIA. E-mail: yustiana@unkhair.ac.id \\ ${ }^{3}$ Department of Accounting, KHAIRUN UNIVERSITY, INDONESIA. E-mail: suwito@unkhair.ac.id \\ ${ }^{4}$ Department of Management, KHAIRUN UNIVERSITY, INDONESIA. E-mail:4irfandi@unkhair.ac.id
}

\begin{abstract}
The purpose of this study is to test the relationship between competency, organizational culture, love of money, and whistleblowing against prevention fraud with spiritual intelligence as moderation. The samples in this study were the village staff of West Halmahera Regency, namely the village head, village secretary, treasurer, head of the village administration section, head of the village development and empowerment section, and the section of village head community development of 213 people. The data in this study were taken using surveys with questionnaires and conducted validity and reliability tests. Hypothesis testing in this study using simple regression analysis and hierarchy. The results showed that out of the eight hypotheses submitted, only five hypotheses were supported and the rest are not supported.
\end{abstract}

Keywords: Competency; Organizational culture; Love of money; whistleblowing; Prevent fraud; Spiritual intelligence.

JEL Classification: D20, M10, M19

Received: June 28, 2021

Accepted: September 30, 2021 


\title{
Determinantes de la Prevención del Fraude con la Inteligencia Espiritual como Moderadora
}

\author{
SURIANA A.R. MAHDI ${ }^{1}$, YUSTIANA DJAELANI ${ }^{2}$, SUWITO ${ }^{3}$, IRFANDI BUAMONABOT ${ }^{4}$ \\ ${ }^{1}$ Department of Accounting, KHAIRUN UNIVERSITY, INDONESIA. E-mail: suriana.mahdi@unkhair.ac.id \\ ${ }^{2}$ Department of Accounting, KHAIRUN UNIVERSITY, INDONESIA. E-mail: yustiana@unkhair.ac.id \\ ${ }^{3}$ Department of Accounting, KHAIRUN UNIVERSITY, INDONESIA. E-mail: suwito@unkhair.ac.id \\ ${ }^{4}$ Department of Management, KHAIRUN UNIVERSITY, INDONESIA. E-mail:4irfandi@unkhair.ac.id
}

\begin{abstract}
RESUMEN
El propósito de este estudio es comprobar la relación entre la competencia, la cultura organizativa, el amor al dinero y la denuncia del fraude preventivo con la inteligencia espiritual como moderación. Las muestras de este estudio fueron el personal de la aldea de la Regencia de Halmahera Occidental, a saber, el jefe de la aldea, el secretario de la aldea, el tesorero, el jefe de la sección de administración de la aldea, el jefe de la sección de desarrollo y empoderamiento de la aldea y la sección de desarrollo comunitario del jefe de la aldea de 213 personas. Los datos de este estudio se tomaron mediante encuestas con cuestionarios y se realizaron pruebas de validez y fiabilidad. La prueba de hipótesis en este estudio utilizando el análisis de regresión simple y la jerarquía. Los resultados mostraron que, de las ocho hipótesis presentadas, sólo cinco fueron apoyadas y el resto no.
\end{abstract}

Palabras clave: Competencia; Cultura organizacional; Amor al dinero, Denuncia de irregularidades; Prevención del fraude; Inteligencia espiritual.

Clasificación JEL: D20, M10, M19 


\section{Introduction}

The village is a boundary of some unitary regions that have the power and authority to take care of the Government for the benefit of the local community by managing village funds sourced from the State Budget through ABPD Transfer and allocated to the Village Budget to improve government services, development, development, and empowerment of village communities (Desa, 2014). The allocation of village funds is stipulated in Regulation of the Minister of Finance no. 4 of 2020 concerning The Management of Village Funds in which it regulates about article 1 paragraph 9-14 explains that the allocation of village funds can be done evenly based on the allocation of Affirmations, Performance Allocation, Formula Allocation, Construction Proficiency Index and Geographic Difficulty Index.

From 2019 to 2021, village funds have disbursed between 70 and 72 Trillion for all villages in Indonesia (Shofihara, 2020), so that the West Halmahera District Government in realizing the Village Fund Financial Management by setting the Regent Regulation on the allocation of village funds management by referring to the Regulation of the Minister of Finance based on affirmation allocation, performance allocation and allocation formula contained in the Regent regulation. From 2017 to 2020, the allocation of village funds has increased significantly. in 2017 the allocated funds amounted to Rp 39,904,768,000, in 2018 amounted to Rp 51,271,745,000, in 2019 amounted to Rp 130,458,534,000 and in 2020 amounted to Rp 110,187,831,000 (Peraturan Bupati Halmahera Barat Tentang Tata Cara Pembagian Dan Penertapan Rincian Alokasi Dana Desa Setiap Desa Dalam Wilayah Kabupaten Halmahera Barat, 2017, 2018, 2019, 2020). This condition reflects that the uptake of the Village Fund budget can run well in accordance with the mandate of the Village Law, the Regulation of the Minister of Finance, and the Regulation of the Minister of Villages on the Priority of The Use of Village Funds.

The priority of the use of Village Fund is intended to realize a fair village community, have natural resources that are evenly distributed, balanced through the arrangement and mapping of Village Potentials and Resources, Village Economic Development, Strengthening Food Security and inclusiveness to realize a healthy, prosperous village without poverty.

The realization of Village Funds must be targeted, transparent and accountable, and free from various frauds. However, in reality, the realization of the use of village funds still leaves various problems. There are still many cases related to the management of village funds. The Inspectorate Audit found evidence of misuse of village funds in 2015 and 2016 in Hatebicara Village by not carrying out some program activities, such as creating business group empowerment roads that can harm the state (Halbar, 2018). Similarly, the Results of the Release of Halmahera Post said that the involvement of the former Head of Togoreba Tua Village, North Mother District of West Halmahera Regency related to the misuse of Village Funds in 2018 could cause state losses of approximately Rp 400 Million (HalmaheraPost, 2020).

Village government officials cause the above conditions in carrying out budget realization actions not guided by the norms that have been set. According to Theory Planned Behavior (TPB) and attitudes, norms and behaviors also control behavior in doing an action. According to Cressey, (1953) and Wolfe \& Hermanson, (2004), fraud occurred due to opportunity, rationalization, pressure, competence, and capability owned by an internal company that can utilize entities' assets for self-interest or specific people. This condition is due to the lack of competence of village resources, unhealthy organizational culture, lack of reward, lack of internal supervision in the village government apparatus, and lack of self-awareness in accounting for the mandate held for the public benefit.

Competence is the ability that a person has in completing the task carried out in accordance with the understanding and knowledge he has. According to Spencer, \& Spencer, (1993), someone who has high competence will improve performance through self-motivation, good self-nature and concept, knowledge, and skills. If this self-competence can be improved, we will be able to deny the occurrence of cheating on a person.

Huslina et al., (2015) showed that the competence of the village apparatus affects the prevention of fraud. However, the research results of Saparman et al., (2020) show that the competence of village 
apparatus has no effect on preventing fraud, but Agusyani et al., (2016) show that the competence of resources affects the prevention of fraud. This result is reinforced by Ardiana \& Sugianto, (2020), showing that the competence of government individuals affects the prevention of fraud. In addition to competence, a good organizational culture can also affect the prevention of fraud.

According to Robbins \& Judge, (2017), a solid organizational culture can influence high ethical standards to affect employee behavior. The results of Afifah's research reinforce the statement, Afiah et al., (2019) and Zelmiyanti \& Anita, (2015), showing that organizational culture can affect fraud prevention. While the research results of Suharto, (2020) showed that Organizational Culture does not affect fraud prevention, but the results of Ferina et al., (2021) show that the organization's culture affects the prevention of fraud. In addition to competence and organizational culture, love of money is also one indicator that can affect the prevention of fraud.

Love of money is a love of money that can positively improve one's performance in completing every pursued work. Research of Akande et al., (2002) show that love of money can impact one's ethical behavior. Tang et al., (2000) research show that low love of money also affects the low satisfaction of one's work. The results of Giovani et al., (2020) show that love of money can affect accounting fraud. In addition, the whistleblowing system is also one of the variables that can affect the prevention of fraud.

A whistleblowing system is a tool used to detect and prevent the possibility of fraud. According to Larasati et al., (2017) whistleblowing system is a form of complaint about fraud involving certain persons inside the entity or outside the entity who take advantage personally within the entity. Agusyani et al., (2016) showed that the whistleblowing system affects Fraud Prevention, but Research of Sujana et al., (2020) showed that the Whistleblowing system does not affect fraud prevention. However, Romadaniati et al., (2020) show that the whistleblowing system affects fraud prevention. Besides competence, organizational culture, love of money, and whistleblowing system that individually affect fraud prevention, spiritual intelligence is also one of the variables that can moderate the relationship between competence, organizational culture, love of money, and whistleblowing prevention fraud.

The results of Romadaniati et al., (2020) show that individual morality moderates the relationship between the competence of village apparatus and fraud prevention, individual morality moderates the relationship between internal control systems and fraud prevention, and individual morality moderates the relationship between whistleblowing system and fraud prevention.

Based on the above phenomena, there are still differences in previous research, so there are still many inconsistencies in variable testing in previous studies, so it is possible to use moderating variables on inconsistent relationships (Baron \& Kenny, 1986). In addition, this study developed the research of Romadaniati et al., (2020). The differences include first; Previous research only used competency variables, internal control systems and whistleblowing system against fraud prevention with individual morals as moderating variables, while this study did not use internal control system variables, but added two independent variables namely, organizational culture and love of money. Second; Previous research examined 103 villages in Bengkalis Regency using 102 respondents, while this research examined 876 village devices in West Halmahera Regency with 213 respondents. Third; Previous studies have used individual morals as moderating variables, while this study used spiritual intelligence as a moderation variable, although the context of both is the same, which is talking about moral consciousness. Spiritual intelligence is one of several types of intelligence and can be developed relatively independently. Spiritual intelligence requires many ways to know and integrate the inner life, mind and soul with outer life such as the world of work and can be developed through individual search, investigation, and practice (Vaughan, 2002). Someone with high spiritual intelligence can prevent fraud (Romadaniati et al., 2020).

It aims explicitly to test and analyze; competence of human resources, organizational culture, love of money, and whistleblowing system against fraud prevention in the management of village budget funds. Interaction of spiritual intelligence to human resource competence, organizational culture, love 
of money, and whistleblowing system prevents fraud in managing village budgets. In addition, spiritual intelligence as a moderating variable has not been used in other studies, especially in the context of village government apparatus

\section{Literature Review}

\subsection{Literature Review}

The research refers to several theoretical foundations, namely pentagon fraud that underlies fraud prevention variables. Pentagon fraud was developed by Wolfe \& Hermanson, (2004), which is the development of triangle fraud theory initiated by Cressey, (1953). The Association of Certified Fruad Examiners defines fraud in financial statements as intentional, misreporting or omission of material facts, or accounting data that can be misleading and when used as a consideration with all available information, will cause users of financial statements to change or change their judgment. or the decision (Zhou \& Kapoor, 2011). In practice, fraud in financial statements consists of manipulation of financial records, intentional omission of significant events, transactions, accounts or other information or misapplication of accounting principles, policies or procedures used to measure, record, report and disclose transactions (Faradiza, 2019). In addition, this study also uses the Theory of Planned Behavior (TPB) developed by Fishbein \& Ajzen, (1975) as the basis of the explanation of the variable love of money, spiritual ingenuity, which according to Ajzen, (1991), Theory of Planned Behavior is based on the assumption that humans are rational beings and use the information that is possible for them, systematically. People think about the implications of their actions before they decide whether or not to perform certain behaviors. In addition, attitudes, norms, and individual subjectivity can also influence a person's behavior in acting.

\subsubsection{Competence}

According to Peraturan Pemerintah Tentang Badan Nasional Sertifikasi Profesi, (2004) nationally recognized work competence is a person's ability to carry out his duties well based on knowledge, skills, and work skills owned by a person. According to Spencer, \& Spencer, (1993), competence is an individual personality in completing a job based on knowledge, skills, attitude, and self-motivation.

\subsubsection{Organizational Culture}

Organizational culture is the beliefs and habits of individuals developed through the system of norms that have been established and used as a guideline in thinking and working to achieve organizational goals. According to Robbins \& Judge, (2017), there are seven that regulate the nature of organizational culture: innovation and risk-taking, attention to detail, the orientation of work, orientation of people, orientation of the team, and aggressiveness of work.

\subsubsection{Love of Money}

According to Tang, (1992), the concept of love for money is a measure of the level of wanting to have money subjectively related to one's level of job satisfaction. Love of money is the root of all kinds of crime but money (income) is not (Tang \& Chiu, 2003; Tang et al., 2007; Tang \& Chen, 2008). Love of money is also defined as the ethics of money or one's desires, and aspirations for money, one's attitude towards money, the meaning of money towards someone, money is not a need, greed, or materialism, individual differences variables, and the combined idea of several sub-constructions or factors (Belk, 1985; Tang, 1995; Mitchell \& Mickel, 1999; Tang et al., 2000; Du \& Tang, 2005; Tang, 2005; Tang et al., 2006; Vitell et al., 2006; Vitell et al., 2007).

\subsubsection{Whistleblowing System}

According to Setiawan, (2021) whistleblowing system is a system provided as a tool to submit complaints about alleged corruption crimes involving people in the internal entity. Whistleblowing is 
an attempt to disclose illegal practices by members of an organization under the control of its leader to individuals or organizations who may provide corrective action (Triantoro et al., 2020). Whistleblowing is the act of employees to disclose certain information that they believe is related to violations of laws, rules, practical guidelines or professional statements and involves improper procedures, corruption, abuse of authority or endangering public safety (Nurhidayat \& Kusumasari, 2018).

\subsubsection{Fraud Prevention}

Fraud is related to intentional deception. Fraud can be defined as the intentional use of tricks, deception, or dishonest acts to eliminate another legal right, property money (Abdullahi \& Mansor, 2018). However, Albrecht et al., (2004), Hopwood, (2008), Rezaee, (2010) states that fraud involves the intentional use of deception and other logical actions to gain an illegal advantage over an entity despite the resulting loss. Ramaswamy, (2005) states that there are several reasons why fraud cases arise, including poor corporate governance and accounting failures. Fraud cases do not only occur in government organizations but also in private organizations (Putra et al., 2019; Yuniar et al., 2020; Ar'Reza et al., 2020).

\subsubsection{Spiritual Intelligence}

According to Zohar \& Marshall, (2007), defining Spiritual Intelligence is a behavior that can solve problems that contain broader values and meanings in life that show the ability of someone who has a flexible attitude, can see problems holistically, understood through values and vision, humble, has a high level of integrity and sincere and submissiveness in dealing with various problems of life.

\subsection{Hypothesis Development}

\subsubsection{Competence of Village Apparatus, Spiritual Intelligence and Fraud Prevention}

Competence is an individual personality in completing a job based on knowledge, skills, attitude, and self-motivation (Spencer \& Spencer, 1993). Huslina et al., (2015) showed that the Comet of village apparatus influenced the prevention of fraud, but the results of Saparman et al., (2020) showed that the competence of village apparatus has no effect on fraud prevention, but Agusyani et al., (2016); showed that the resource extension affects fraud prevention. The results of this study are reinforced by Romadaniati et al., (2020) that partially show that the government's individual competence affects fraud prevention. The results of Romadaniati et al., (2020) also showed that individual morality could moderate competence towards fraud prevention. Therefore, from the results of the above research, the first hypothesis is determined:

$\mathrm{H} 1 \mathrm{a}$. The competence of village government officials affects the prevention of fraud

$\mathrm{H} 1 \mathrm{~b}$. Spiritual intelligence moderates the influence of competency of village government apparatus on fraud prevention

\subsubsection{Organizational Culture, Spiritual Intelligence, and Fraud Prevention}

A solid organizational culture influences high ethical standards that should have a powerful and positive influence on employee behavior (Robbins \& Judge, 2017). This statement was later strengthened by Afiah et al., (2019), that organizational culture can affect fraud prevention. While the results of Research Suharto, (2020) showed that organizational culture does not affect fraud prevention, the results of the study, but the results of Ferina et al., (2021) show that the organization's culture affects the prevention of fraud. According to Robbins \& Judge, (2017), cultural organizations can influence high ethical standards to influence employee behavior. Culture can be strengthened by spiritual intelligence that a person has to prevent the occurrence of cheating, so from the description above, the second hypothesis is determined:

$\mathrm{H} 2 \mathrm{a}$. Organizational culture influences fraud prevention 
$\mathrm{H} 2 \mathrm{~b}$. Spiritual intelligence moderates the influence of organizational culture on fraud prevention

\subsubsection{Love of Money, Spiritual intelligence dan Fraud Prevention}

The concept of love for money is a measure of the level of wanting to have money subjectivity related to one's level of job satisfaction (Tang, 1992). Result of research Akande et al., (2002) show that love of money can impact one's ethical behavior. This result is reinforced by Giovani et al., (2020), showing that love of money can affect the tendency of accounting fraud. The money ethic scale (MES) developed by Tang, (1992) is used to measure a person's ethical attitude towards his assessment of money. The ethical attitude can be strengthened by spiritual intelligence in preventing fraud. Therefore, from the results of the above research, hypotheses are determined as follows:

H3a. love of money affects fraud prevention

$\mathrm{H} 3 \mathrm{~b}$. Spiritual intelligence moderates the influence of the love of money on fraud prevention

\subsubsection{Whistleblowing System and Fraud Prevention}

According to Larasati et al., (2017) whistleblowing system is a form of complaint about fraud involving certain people inside the entity. The research results by Agusyani et al., (2016) showed that the whistleblowing system affects the prevention of fraud, but Sujana et al., (2020) showed that whistleblowing system does not affect fraud prevention. However, research by Romadaniati et al., (2020) showed that whistleblowing affects prevention.

H4a. Whistleblowing system affects fraud prevention

$\mathrm{H} 4 \mathrm{~b}$. Spiritual intelligence moderates the influence of the whistleblowing system on fraud prevention

\section{Methodology}

This study uses quantitative methods. The data in this study were collected by survey method using a questionnaire. with a survey approach. Surveys are an appropriate method for measuring a person's behavior (Neuman, 2011). The samples in this study are village official in West Halmahera Regency. The population in this study amounted to 876 village devices. The samples in this study were taken using the nonprobability sampling method, namely purposive sampling with consideration of village official-always involved in the preparation of village budgets (APBDes), namely village heads, village secretaries, treasurers, heads of sections in the field of village governance, heads of village development and empowerment sections and heads of village community development sections totaling 213 respondents. According to Roscoe et al., (1975), the ideal number of samples in quantitative research is between 30-500 respondents, so a total of 213 people are considered appropriate. Instrument testing in this study used validity and reliability tests. The validity test in this study used analysis of factors with a loading factor value is $\geq 0.5$ (Hair, Jr., 2015), while the reliability test is using Cronbach's Alpha $\geq$ value of 0.7 (Hair et al., 2010). Hypothesis testing 1, 2, 3, and 4 using simple regression analysis (Hair et al., 2018) and hypotheses $1 \mathrm{a}, 1 \mathrm{~b}, 1 \mathrm{c}$, and $1 \mathrm{~d}$ using hierarchical regression analysis (Baron \&Kenny, 1986). The questionnaire in this study was adopted from previous research which has been adapted to the context of the village government and used the Likert 5 scale strongly disagree to strongly agree. For the competency variable using a questionnaire developed by Aruan, (2003). Organizational culture variable using a questionnaire adopted from Trisnaningsih, (2007). For the love of money variable using a questionnaire developed by Tang, (1992). Furthermore, the whistleblowing variable uses a questionnaire adapted from Semendawai et al., (2011). Next, spiritual intelligence uses a questionnaire developed by Zohar \& Marshall, (2007). Lastly, for the Fraud Prevention variable using a questionnaire developed by Tunggal, (2013). 


\section{Results and Discussion}

\subsection{Results}

Based on the results of the spread of questionnaires showed that only 213 questionnaires were declared eligible for further testing out of a total of 219 questionnaires distributed, so the response rate in this study was $97 \%$. The demographic characteristics in this study are age, position, gender, marital status, and education. Respondents in the study were mainly between the ages of 47-55, with varying positions, then dominated by male and married respondents, with the most levels of education being graduates of high school.

Table 1 Respondent Description

\begin{tabular}{|c|c|c|}
\hline Variable & Frequency & $(\%)$ \\
\hline \multicolumn{3}{|l|}{ Age } \\
\hline 25-35 у.о. & 12 & 5.63 \\
\hline 36-46 у.о. & 79 & 37.09 \\
\hline $47-55$ у.о. & 105 & 49.30 \\
\hline$>56$ у.о. & 17 & 7.98 \\
\hline Total & 213 & 100 \\
\hline \multicolumn{3}{|l|}{ position } \\
\hline village head & 35 & 16.43 \\
\hline Village Secretary & 45 & 21.13 \\
\hline treasurer & 37 & 17.37 \\
\hline Head of Section of Village Government Administration & 30 & 14.08 \\
\hline Head of Village Development and Empowerment Section & 34 & 15.96 \\
\hline Head of Village Community Development Section & 32 & 15.02 \\
\hline Total & 213 & 100 \\
\hline \multicolumn{3}{|l|}{ Gender } \\
\hline Man & 197 & 92.49 \\
\hline Woman & 16 & 7.51 \\
\hline Total & 213 & 100 \\
\hline \multicolumn{3}{|l|}{ Marital status } \\
\hline Unmarried & 27 & 12.68 \\
\hline Married & 186 & 87.32 \\
\hline Total & 213 & 100 \\
\hline \multicolumn{3}{|l|}{ Education } \\
\hline Normally secondary school & 3 & 1.41 \\
\hline High School & 146 & 68.54 \\
\hline Under graduate & 64 & 30.05 \\
\hline Total & 213 & 100 \\
\hline
\end{tabular}

Source: processed data

The descriptive analysis results consist of competency, organizational culture, love of money, whistleblowing, spiritual intelligence, and prevent fraud (see table 1). The results showed that respondents perceive agreeing that competency is appropriate. Furthermore, for organizational culture, respondents perceive the organization's culture run by the organization itself is in good condition. Respondents also perceive the love of money at a high level. it means that respondents have a strong desire to have money objectively. Respondents also agreed that a high level of whistleblowing occurred. Furthermore, respondents perceive to agree that the life carried out is appropriate and 
better than others for spiritual intelligence. Lastly, respondents also agreed to take precautions related to preventing fraud.

Table 1 Respondents Perception on Competency, Organizational Culture, Love of Money, Whistleblowing, Spiritual Intelligence, Prevention Fraud

\begin{tabular}{lcccccc}
\hline \multicolumn{1}{c}{ Variable } & $\begin{array}{c}(\%) \\
\text { Strongly } \\
\text { Disagree }\end{array}$ & $\begin{array}{c}(\%) \\
\text { Disagree }\end{array}$ & $\begin{array}{c}\text { (\%) } \\
\text { Neutral }\end{array}$ & $\begin{array}{c}\text { (\%) } \\
\text { Agree }\end{array}$ & $\begin{array}{c}\text { (\%) } \\
\text { Strongly } \\
\text { Agree }\end{array}$ & Mode \\
\hline Competency & - & - & 5.16 & 77 & 17.84 & Agree \\
$\begin{array}{l}\text { Organizational } \\
\text { Culture }\end{array}$ & - & 2.82 & 1.88 & 69.48 & 25.82 & Agree \\
$\begin{array}{l}\text { Love of Money } \\
\text { Whistleblowing }\end{array}$ & - & - & 3.76 & 57.75 & 38.50 & Agree \\
$\begin{array}{l}\text { Spiritual Intelligence } \\
\text { Prevention Fraud }\end{array}$ & - & - & 12.68 & 71.36 & 15.96 & Agree \\
\hline \multicolumn{1}{l}{ Source: Data Process } & - & - & 11.27 & 73.24 & 15.49 & Agree \\
\hline
\end{tabular}

The validity test results in table 3 show that question items from competency, organizational culture, love of money, whistleblowing, and spiritual intelligence variables should be discarded because they do not meet the loading factor 0.5 and are considered invalid. After removing a question that is considered invalid, the question item of each variable is considered valid. Furthermore, reliability test results show that the question item on each variable already meets Cronbach alpha 0.7, so it is considered reliable. The validity and reliability test results are shown in Table 1.

Table 2 Validity and Reliability Test Results

\begin{tabular}{llllllll}
\hline Factor & $\begin{array}{c}\text { Factor } \\
\mathbf{1}\end{array}$ & $\begin{array}{c}\text { Factor } \\
\mathbf{2}\end{array}$ & $\begin{array}{c}\text { Factor } \\
\mathbf{3}\end{array}$ & $\begin{array}{c}\text { Factor } \\
\mathbf{4}\end{array}$ & $\begin{array}{c}\text { Factor } \\
\mathbf{5}\end{array}$ & $\begin{array}{c}\text { Factor } \\
\mathbf{6}\end{array}$ & $\begin{array}{c}\text { Cronbach } \\
\text { alpha }\end{array}$ \\
\hline Cy3 & 0.774 & & & & & \\
Cy4 & 0.791 & & & & & \\
Cy5 & 0.823 & & & & & \\
Cy6 & 0.604 & & & & & \\
Cy9 & 0.774 & & & & & \\
Cy10 & 0.791 & & & & & \\
Cy11 & 0.823 & & & & \\
Cy12 & 0.604 & & & & \\
Cy15 & 0.774 & & & & \\
Cy16 & 0.791 & & & & \\
Cy17 & 0.823 & & & & \\
Cy18 & 0.604 & & & & \\
Cy20 & 0.763 & & & & \\
Cy21 & 0.826 & & & & \\
Cy22 & 0.823 & & & & \\
Cy23 & 0.604 & & & & \\
OC1 & & 0.831 & & & \\
OC5 & & 0.699 & & & \\
OC6 & & 0.894 & & & \\
OC7 & & 0.722 & & & \\
OC8 & & 0.689 & & & & \\
LoM1 & & & 0.546 & & \\
LoM4 & & 0.536 & & \\
LoM6 & & 0.793 & & \\
LoM7 & & & 0.894 & & \\
LoM8 & & & 0.791 & & \\
Wg1 & & & & & \\
& & & & \\
\end{tabular}




\begin{tabular}{|c|c|c|c|c|c|c|c|}
\hline Factor & $\begin{array}{l}\text { Factor } \\
1\end{array}$ & $\begin{array}{l}\text { Factor } \\
2\end{array}$ & $\begin{array}{l}\text { Factor } \\
3\end{array}$ & $\begin{array}{l}\text { Factor } \\
4\end{array}$ & $\begin{array}{l}\text { Factor } \\
5\end{array}$ & $\begin{array}{l}\text { Factor } \\
6\end{array}$ & $\begin{array}{l}\text { Cronbach } \\
\text { alpha }\end{array}$ \\
\hline Wg2 & & & & 0.831 & & & \\
\hline Wg3 & & & & 0.646 & & & 0,833 \\
\hline Wg6 & & & & 0.785 & & & \\
\hline Wg7 & & & & 0.640 & & & \\
\hline Wg8 & & & & 0.815 & & & \\
\hline Sle3 & & & & & 0.847 & & \\
\hline Sle4 & & & & & 0.810 & & \\
\hline Sle5 & & & & & 0.775 & & 0,892 \\
\hline Sle8 & & & & & 0.847 & & \\
\hline Sle9 & & & & & 0.805 & & \\
\hline Sle10 & & & & & 0.777 & & \\
\hline FP1 & & & & & & 0.563 & \\
\hline FP2 & & & & & & 0.836 & \\
\hline FP3 & & & & & & 0.814 & 0.792 \\
\hline FP7 & & & & & & 0.825 & \\
\hline FP8 & & & & & & 0.768 & \\
\hline & & $\overline{R e m a r k}$ & $\begin{array}{l}\text { :Competer } \\
\text { Whistleblov }\end{array}$ & $\begin{array}{l}\text { y), Organ } \\
\text { Ng), Spir }\end{array}$ & $\begin{array}{l}\text { nal Cultu } \\
\text { ntelligenc }\end{array}$ & $\begin{array}{l}\text { ve of Mor } \\
\text { ), Fraud }\end{array}$ & $\begin{array}{l}\mathrm{oM}), \\
\text { ntion (FP) }\end{array}$ \\
\hline
\end{tabular}

The results of hypothesis testing in table 2 show that competency has a significant positive effect on fraud prevention $(\beta=0,203, t=3,390, P<0.05)$, so hypothesis1 is supported. Hypothesis 2 indicates that organizational culture has no significant negative effect on fraud prevention $(\beta=-0,004, t=-0,067$, $P>0.05$ ), so hypothesis 2 is not supported. Hypothesis 3 also shows that love of money has a significant positive effect on fraud prevention $(\beta=0,260, t=3,685, P<0.05)$, so hypothesis 3 is not supported in this study. Similar to hypotheses 1 and 3 , hypothesis 4 is also supported in this study. The test results showed that whistleblowing also had a positive effect on fraud prevention $(\beta=0,178, t=3,578, P<$ 0.05).

Table 3 Hierarchy Regression and Regression Test Results

\begin{tabular}{|c|c|c|c|c|}
\hline \multirow{2}{*}{ Variable Independent } & \multicolumn{4}{|c|}{ Prevention Fraud } \\
\hline & $\beta$ & $\mathbf{t}$ & $\mathbf{R}^{2}$ & Sig \\
\hline Competency* $^{*}$ & 0,203 & 3,390 & 0,052 & 0,001 \\
\hline Spiritual Intelligence ${ }^{\star \star}$ & 0,388 & 8,250 & 0,284 & 0,000 \\
\hline${\text { Competency }{ }^{*} \text { Spiritual Intelligence }}^{\star \star *}$ & 0,407 & 4,682 & 0,352 & 0,000 \\
\hline Organizational Culture* & $\begin{array}{r}- \\
0,004\end{array}$ & $\begin{array}{r}- \\
0,067\end{array}$ & 0,000 & 0,947 \\
\hline Spiritual Intelligence ${ }^{\star \star}$ & 0,451 & 9,766 & 0,312 & 0,000 \\
\hline 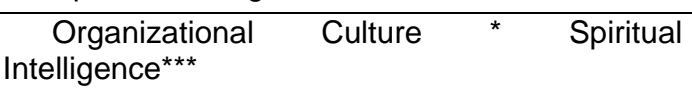 & 0,686 & 7,631 & 0,452 & 0,000 \\
\hline Love of Money* & 0,260 & 3,685 & 0,060 & 0,000 \\
\hline Spiritual Intelligence ${ }^{\star \star}$ & 0,382 & 8,737 & 0,296 & 0,000 \\
\hline Love of Money * Spiritual Intelligence ${ }^{\star \star \star}$ & 0,501 & 4,416 & 0,356 & 0,000 \\
\hline Whistleblowing* & 0,178 & 3,579 & 0,057 & 0,000 \\
\hline Spiritual Intelligence ${ }^{\star \star}$ & 0,403 & 8,047 & 0,279 & 0,000 \\
\hline Whistleblowing * Spiritual Intelligence ${ }^{\star \star *}$ & 0,036 & 0,263 & 0,280 & 0,793 \\
\hline
\end{tabular}


Testing of moderation hypothesis 1a shows that spiritual intelligence strengthens the relationship between competency and prevention fraud. This tendency can be seen from the rise of the value of $R 2$ in all three equations and has a significant positive direction $(\beta=0,407, t=4,682, P<0.05)$ so that hypothesis $1 \mathrm{a}$ is supported. Furthermore, hypothesis $1 \mathrm{~b}$ shows that spiritual intelligence strengthens the relationship between organizational culture and prevention fraud. This can be seen in the third equation $(\beta=0,686, t=7,631, P<0.05)$ and the value of $R 2$ increased. Similar to hypotheses $1 \mathrm{a}$ and $1 \mathrm{~b}$, hypothesis $1 \mathrm{c}$ also suggests spiritual intelligence strengthens the relationship between love of money and prevention fraud. This result can be seen in the third equation $(\beta=0,551, t=4,416, P<0.05)$ and the increase in the value of $R 2$ in all three equations. Lastly, the $1 \mathrm{~d}$ hypothesis suggests that spiritual intelligence is not a moderation on the relationship between whistleblowing and prevention fraud. This result can be seen in the third equation, although it shows strengthening the relationship between the two variables but not significant $(\beta=0,036, t=0.263, P>0.05)$, so related to the results of moderation testing, only the $1 \mathrm{~d}$ hypothesis is not supported in this study.

\subsection{Discussion}

\subsubsection{Competency of Village Apparatus and Fraud Prevention}

The results showed that competence affects the prevention of fraud. This result shows that the higher the level of competence of a village government official, the more it increases fraud prevention in the West Halmahera Regency. This is because in general, village government officials have expertise and experience that can improve their performance in managing village finances, so that they are able to prevent themselves from committing fraud. The results of this study are not in line with research Saparman et al., (2020), showing that the competence of village apparatus has no effect on fraud prevention, but the results of this study strengthen the results of research Huslina et al., (2015), Agusyani et al., (2016), Romadaniati et al., (2020) showed that resource competence affects fraud prevention.

\subsubsection{Competence of Village Apparatus, Spiritual Intelligence and Fraud Prevention}

The results showed that spiritual intelligence could moderate the influence of the competency of village government apparatuses on fraud prevention. The results of this study show that Spiritual Intelligence can strengthen the influence of competence on fraud prevention. The results of this study are in line with the research of Romadaniati et al., (2020), which shows that individual morality can moderate competence towards the prevention of fraud. This result indicates that in addition to the spiritual intelligence of a village government apparatus will strengthen the influence of competence on the prevention of fraud of village funds in the West Halmahera Regency.

\subsubsection{Organizational Culture and Fraud Prevention}

The results showed that the culture of the organization does not affect the Prevention of Fraud. This result shows that the role of culture in the working environment of the village government apparatus cannot affect fraud prevention. For them, organizational culture is not important to prevent the possibility of fraud, because in addition to the various ethnicities and cultures that each individual has, individual work is also an achievement for those who can prevent the possibility of fraud. These results are not in line with the research of Afiah et al., (2019), and Ferina et al., (2021) showed that the culture of the organization affects the prevention of fraud, but this study in line with research Suharto, (2020) shows that the culture of the organization does not affect the prevention of fraud.

\subsubsection{Organizational Culture, Spiritual Intelligence, and Fraud Prevention}

The results showed that Spiritual Intelligence could moderate the influence of culture on fraud prevention. This result shows that, although partially, the culture of the village government apparatus organization does not affect spiritual intelligence, the role of spiritual intelligence can strengthen the influence of organizational culture on the prevention of fraud. This study showed that the role of 
culture in the working environment of the village government apparatus could affect the prevention of fraud by strengthened by the spiritual intelligence of a village government apparatus of West Halmahera Regency. For them, organizational culture is not important to prevent the possibility of fraud. This is because, various ethnic cultures are considered more important, thus ignoring organizational culture in a government, but spiritual intelligence is able to strengthen the influence of organizational culture on fraud prevention, because the higher one's spiritual level of awareness can increase awareness and shape one's behavior better in work and will form a healthy organizational culture and can prevent the possibility of fraud.

\subsubsection{Love of Money and Fraud Prevention}

The results showed that love of money affects the prevention of fraud. The results of this study strengthen the results of Tang (1992) research which shows that high achievers tend to earn more money and can prevent the possibility of fraud. This result also reinforces their statement that the ability to complete individual work can improve their performance and prevent the possibility of fraudulent village funds. This result shows that the higher the love of money owned by a village government official, it can increase the prevention of fraud in the West Halmahera Regency Village Government. Love of money shows that a motivated government official works more vigorously and more diligently to earn money to meet his life's needs.

\subsubsection{Love of Money, Spiritual Intelligence and Fraud Prevention}

The results showed that spiritual intelligence could moderate the influence of the love of fraud prevention. These results show that spiritual intelligence can strengthen the influence of the love of money on fraud prevention. These results indicate that village government officials who have high spiritual intelligence can provide awareness of the importance of financial management and can increase their love of money through their achievements, so as to prevent the possibility of fraudulent village funds. The money ethic scale (MES) developed by Tang, (1992) is used to measure a person's ethical attitude towards his assessment of money; such ethical attitudes can be strengthened by spiritual intelligence in preventing fraud.

\subsubsection{Whistleblowing System and Fraud Prevention}

The results showed that the whistleblowing system affects fraud prevention. These results indicate that a secure internal control system can be a protector for village government officials, so as to prevent the possibility of fraud. This is also indicated by the respondent's statement stating that the availability of a complaint system and reporting of complaints for internal fraud of the village government can prevent fraud in village funds. The results of this study are not in line with the research of Sujana et al., (2020) showed that the whistleblowing system has no effect on Fraud Prevention, but the results of this study strengthen the results of research Agusyani et al., (2016), and Romadaniati et al., (2020) showed that whistleblowing system affects fraud prevention.

\subsubsection{Whistleblowing System, Spiritual Intelligence and Fraud Prevention}

The results showed that spiritual intelligence does not moderate the influence of the whistleblowing system on fraud prevention. The results of this study did not Romadaniati et al., (2020) show that individual morality can moderate the whistleblowing system against fraud prevention. These results show that Spiritual Intelligence is not a moderation on the influence of the whistleblowing system on fraud prevention. Based on the results of respondents, it shows that the village government whistleblowing system has been implemented properly, such as the complaint system and reporting policies on allegations of possible fraud can work well and can prevent the possibility of fraud, so that a high level of spiritual intelligence for village government officials cannot strengthen the effect of the whistleblowing system on fraud prevention. 


\section{Conclusion}

The conclusions in this study are first, the competence of village government apparatus resources has an effect on fraud prevention. second, spiritual intelligence can moderate the influence of the competence of village government apparatus resources on fraud prevention. third, organizational culture within the village government has an effect on fraud prevention. fourth, spiritual intelligence can moderate the influence of organizational culture within the village government on fraud prevention. Fifth, Love of money village government apparatus has an effect on fraud prevention. the sixth, spiritual intelligences can moderate the effect of love of money by village government officials on fraud prevention. seventh, the whistleblowing system within the village government has an effect on fraud prevention. eighth, spiritual intelligence does not moderate the influence of the whistleblowing system within the village government on fraud prevention.

\section{References}

1. Abdullahi, R., \& Mansor, N. (2018). Fraud prevention initiatives in the Nigerian public sector: Understanding the relationship of fraud incidences and the elements of fraud triangle theory. Journal of Financial Crime, 25(2), 527-544. https://doi.org/10.1108/JFC-02-2015-0008

2. Afiah, N. N., Syatyakti, Y., Alfian, A., \& Sueb, M. (2019). Fraud prevention capability and organizational culture: A case study of government agencies. Opcion, 35, 996-1011.

3. Agusyani, N. K. S., Sujana, E., \& Wahyuni, M. A. (2016). Pengaruh Whistleblowing System dan Kompetensi Sumber Daya Manusia Terhadap Pencegahan Fraud pada Pengelolaan Keuangan Penerimaan Pendapatan Asli Daerah (Studi pada Dinas Pendapatan Daerah Kabupaten Buleleng). E-Journal Akuntansi, 6(3), 1-10. https://doi.org/http://dx.doi.org/10.23887/jimat.v6i3.8801

4. Ajzen, I. (1991). The Theory of Planned Behavior. Organizational Behavior and Human Decision Processes, 50(2), 179-211. https://doi.org/10.1016/0749-5978(91)90020-T

5. Akande, A., Alzubaidi, A. S., Borg, M. G., Cheng, B.-S., Chiu, R. K., Jen, C.-K., Kazem, A. M., Lim, V. K. G., Malovics, E., Osagie, J. E., Pholsward, R., Sardzoska, E., Stembridge, A. F., Sutarso, T., Tang, T. L.N., Teo, T. S. H., \& Vlerick, P. (2002). Is "The Love of Money" The Root of All Evil? or Different Strokes for Different Folks: Lessons in 12 Countries Thomas Li-Ping Tang. BRC Paper on Cross-Cultural Management, School of Business, Hong kong Baptis University.

6. Albrecht, W., Albrecht, C. C., \& Albrecht, C. O. (2004). Fraud and corporate executives: Agency, stewardship and broken trust. Journal of Forensic Accounting, 5, 109-130.

7. Ar'Reza, I. F., Wardoyo, C., \& Putri, S. F. (2020). Internal Auditors' Fraud Detection: A Phenomenological Study. International Journal of Accounting \& Finance in Asia Pasific, 3(2), 68-76. https://doi.org/10.32535/ijafap.v3i2.836

8. Ardiana, T. E., \& Sugianto, L. O. (2020). The Influence of Financial Reporting Compliance, Government Personnel Competency Towards Fraud Prevention in Village Fund Management. International Journal of Economics, Business and Accounting Research, 4(4), 1265-1275. http://www.jurnal.stie-aas.ac.id/index.php/IJEBAR/article/view/1556

9. Aruan, N. (2003). Kompetensi Aparatur Pemerintah Daerah Studi Empiris di Jawa Timur. Badan Penelitian dan Pengembangan Propinsi Jawa Timur.

10.Baron, R., \& Kenny, D. (1986). The moderator-mediator variable distinction in social psychological research. Journal of Personality and Social Psychology, 51(6), 1173-1182.

https://doi.org/10.1037/0022-3514.51.6.1173

11.Belk, R. W. (1985). Materialism: Trait Aspects of Living in the Material World. Journal of Consumer Research, 12(3), 265-280. https://doi.org/10.1086/208515

12.Cressey, D. R. (1953). Other People's Money. Glencoe, III Free Press.

13.Du, L., \& Tang, T. L. P. (2005). Measurement invariance across gender and major: The love of money among university students in People's Republic of China. Journal of Business Ethics, 59(3), 281-293. https://doi.org/10.1007/s10551-004-6395-4

14.Faradiza, S. A. (2019). Fraud pentagon dan kecurangan laporan keuangan. EkBis: Jurnal Ekonomi 
Dan Bisnis, 2(1), 1-22. https://doi.org/10.14421/EkBis.2018.2.1.1060

15.Ferina, I. S., Mulyani, S., Afia, N. N., \& Poulus, S. (2021). The Zero Fraud Implementation Through the Innovation of Information Technology and Organizational Culture. Journal of Southwest Jiaotong University, 56(1), 324-334. https://doi.org/10.35741/issn.0258-2724.56.1.30

16.Fishbein, M., \& Ajzen, I. (1975). Belief, attitude, intention, andbehavior: An introduction to theory and research. Reading,MA: Addison-Wesley.

17.Giovani, A., Wibowo, A.S, \&, \& Yanuarisa, Y. (2020). Pengaruh love of money dan religiusitas terhadap kecenderungan fraud accounting dana desa dengan gender sebagai variabel moderasi pada desa di kecamatan katingan tengah. Balance, 12(6), 2. https://e-journal.upr.ac.id/index.php/blnc/article/view/1879

18. Hair, J. F., Babin, B. J., Anderson, R. E., \& Black, W. C. (2018). Multivariate Data Analysis (8th ed.). Cengange India.

19.Hair, Joseph, Black, W., Babin, B., \& Anderson, R. (2010). Multivariate Data Analysis: A Global Perspective (7th ed.). Pearson.

20.Hair, Jr, Wolfinbarger, M., Money, A. H., Samouel, P., \& Page, M. J. (2015). Essentials of Business Research Methods (3rd ed.). Routledge. https://doi.org/10.4324/9781315704562

21. Halbar, H. P. (2018). Kasus Terduga Pelanggar Penyalahgunaan Anggaran Dana Desa Oleh Mantan Kepala Desa Hatebicara. Humas Polres Halmahera Barat. http://halbar.malut.polri.go.id/kasusterduga-pelanggar-penyalahgunaan-anggaran-dana-desa-oleh-mantan-kepala-desa-hatebicara/

22. HalmaheraPost. (2020). Mantan Kades Togoreba Sungi di Halmahera Barat Berhasil Diringkus Kejari. Halmahera Post. https://halmaherapost.com/2020/11/08/mantan-kades-togoreba-sungidi-halmahera-barat-berhasil-diringkus-kejari/

23. Hopwood, W. L. (2008). Forensic Accounting. McGraw Hill.

24. Huslina, H., Islahuddin, \& Syah, N. (2015). Pengaruh Integritas Aparatur, Kompetensi Aparatur, dan Pemanfaatan Teknologi Informasi Terhadap Efektivitas Sistem Pencegahan Fraud. Jurnal Administrasi Akuntansi : Program Pascasarjana Unsyiah, 4(1), 55-64.

http://www.jurnal.unsyiah.ac.id/JAA/article/view/4455

25.Larasati, Y. S., Sadeli, D., \& Surtikanti, S. (2017). Analisis Faktor-Faktor Yang Berpengaruh Terhadap Pencegahan Fraud Di Dalam Proses Pengadaan Barang Dan Jasa. JIAFE (Jurnal IImiah Akuntansi Fakultas Ekonomi), 3(2), 43-60. https://doi.org/10.34204/jiafe.v3i2.759

26. Mitchell, T. R., \& Mickel, A. E. (1999). The Meaning of Money : Difference Perspective Perspective Difference. Academy of Management Review, 24(3), 568-578.

https://doi.org/10.5465/amr.1999.2202138

27.Neuman, W. L. (2011). Basics of Social Research: Qualitative and Quantitative Approaches (7th ed.). Pearson.

28.Nurhidayat, I., \& Kusumasari, B. (2018). Strengthening the Effectiveness of Whistleblowing System A Study for the Implementation of Anti-Corruption Policy in Indonesia Abstract. Journal of Financial Crime, 25(1), 140-154. https://doi.org/10.1108/JFC-11-2016-0069

29.Peraturan Pemerintah tentang Badan Nasional Sertifikasi Profesi, (2004). https://jdih.kemnaker.go.id/data_wirata/2004-3-2.pdf

30.Peraturan Bupati Halmahera Barat Tentang Tata Cara Pembagian Dan Penertapan Rincian alokasi Dana Desa Setiap Desa Dalam Wilayah Kabupaten Halmahera Barat, (2017). https://jdih.halbarkab.go.id/detail.php?id=1597

31.Peraturan Bupati Halmahera Barat Tentang Tata Cara Pembagian Dan Penertapan Rincian alokasi Dana Desa Setiap Desa Dalam Wilayah Kabupaten Halmahera Barat, (2018). https://jdih.halbarkab.go.id/detail.php?id=2009

32.Peraturan Bupati Halmahera Barat Tentang Tata Cara Pembagian Dan Penertapan Rincian alokasi Dana Desa Setiap Desa Dalam Wilayah Kabupaten Halmahera Barat, (2019). https://jdih.halbarkab.go.id/detail.php?id=2052

33.Peraturan Bupati Halmahera Barat Tentang Tata Cara Pembagian Dan Penertapan Rincian alokasi Dana Desa Setiap Desa Dalam Wilayah Kabupaten Halmahera Barat, (2020). 
https://jdih.halbarkab.go.id/detail.php?id=2276

34.Putra, I. G. C., Saitri, P. W., \& Gunadi, I. G. B. N. (2019). Accounting Fraud Tendency on Village Credit Institution. International Journal of Accounting \& Finance in Asia Pasific (IJAFAP), 2(2), 1-9. https://doi.org/10.32535/ijafap.v2i2.538

35.Ramaswamy, V. (2005). Corporate Governance and the Forensic Accountant. The CPA Journal, 75(3), 68-70. https://www.proquest.com/openview/d43e3bef97c0fc246721ddc3f52d47c8/1?pqorigsite $=$ gscholar $\& \mathrm{cbl}=41798$

36.Rezaee, Z. (2010). Financial Statement Fraud- Prevention and Detection (2nd ed.). John Wiley \& Sons.

37.Robbins, S. P., \& Judge, T. A. (2017). Organizational Behavior (17th ed.). Pearson.

38.Romadaniati, R., Taufik, T., \& Nasir, A. (2020). Pengaruh Kompetensi Aparatur Desa, Sistem Pengendalian Internal dan Whistleblowing System terhadap Pencegahan Fraud pada Pemerintahan Desa dengan Moralitas Individu sebagai Variabel Moderasi (Studi pada Desa-Desa di Kabupaten Bengkalis). Bilancia: Jurnal Ilmiah Akuntansi, 4(3), 227-237.

http://www.ejournal.pelitaindonesia.ac.id/ojs32/index.php/BILANCIA/article/view/734

39.Roscoe, A. M., Lang, D., \& Sheth, J. N. (1975). Follow-up Methods, Questionnaire Length, and Market Differences in Mail Surveys: In this experimental test, a telephone reminder produced the best response rate and questionnaire length had no effect on rate of return. Journal of Marketing, 39(2), 20-27. https://doi.org/10.1177\%2F002224297503900205

40.Saparman, Ridwan, Din, M., Jamaluddin, Laupe, S., Iqbal, M., \& Betty. (2020). The Effect of Local Apparatus Competence, Financial Reporting Compliance and Internal Control Environment on Fraud Prevention: The Role of Local Assistants as Moderation Variable. Proceedings of the International Conference on Strategic Issues of Economics, Business and, Education, 163, 57-60. https://doi.org/10.2991/aebmr.k.210220.011

41.Semendawai, A. H., Santoso, F., Wagiman, W., Omas, B., \& Susilaningtias, S. M. W. (2011). Memahami whistleblower. Lembaga Perlindungan Saksi dan Korban (LPSK).

42.Setiawan, H. (2021). Whistleblower System. Badan Pengawas Keuangan Dan Pembangunan. http://www.bpkp.go.id/ jateng/konten/1911/Whistleblower-System.bpkp

43.Shofihara, I. J. (2020, November 12). Pada 2021 Belanja Dana Desa Akan Digelontorkan Sebesar Rp 72 Triliun. Kompas.Com. https://nasional.kompas.com/read/2020/12/11/10015011/pada-2021belanja-dana-desa-akan-digelontorkan-sebesar-rp-72-triliun?page=all

44.Spencer, L, M., \& Spencer, S, M. (1993). Models for superior performance. wiley.

45.Suharto. (2020). The Effect of Organizational Culture, Leadership Style, Whistleblowing Systems, and Know Your Employee on Fraud Prevention in Sharia Banking. Asia Pasific Fraud Journal, 5(1), 108-117. https://doi.org/10.21532/apfjournal.v5i1.141

46.Sujana, I. K., Suardikha, I. M. S., \& Laksmi, P. S. P. (2020). Whistleblowing System, Competence, Morality, and Internal Control System Against Fraud Prevention on Village Financial Management in Denpasar. E-Jurnal Akuntansi, 30(11), 2780-2794. https://doi.org/10.24843/eja.2020.v30.i11.p06

47.Tang, T. L.-P. (1992). The Meaning of Money Revisited. Journal of Organizational Behavior, 13(2), 197-202. https://www.jstor.org/stable/2488183

48.Tang, T. L.-P., Kim, J. K., \& Tang, D. S.-H. (2000). Does attitude toward money moderate the relationship between intrinsic job satisfaction and voluntary turnover? Human Relations, 53(2), 213-245. https://doi.org/10.1177/a010560

49.Tang, T. L. (2005). The Economy and Its Impacts on the Challenges of Human Resource Management. Psihologia Resurselor Umane, 3(2), 11-15.

50.Tang, T. L., \& Chiu, R. K. (2003). Income, Money Ethic, Pay Satisfaction, Commitment, and Unethical Behavior: Is the Love of Money the Root of Evil for Hong Kong Employees? Journal of Business Ethics, 46, 13-30. https://doi.org/10.1023/A:1024731611490

51.Tang, T. L. P., Sutarso, T., Akande, A., Allen, M. W., Alzubaidi, A. S., Ansari, M. A., Arias-Galicai, F., Borg, M. G., Canova, L., Charles-Pauvers, B., Cheng, B. S., Chiu, R. K., Du, L. Z., Garber, I., Torre, C. G. de la, Higgs, R. C., Ibrahim, A. H. S., Jen, C. K., Kazem, A. M., ... Vlerick, P. (2007). Doing Well by Doing 
Good: Does Economic Development Make a Difference? Academy of Management Annual Meetings, 3-8.

52.Tang, Thomas Li Ping. (1995). The development of a short Money Ethic Scale: Attitudes toward money and pay satisfaction revisited. Personality and Individual Differences, 19(6), 809-816. https://doi.org/10.1016/S0191-8869(95)00133-6

53.Tang, Thomas Li Ping, \& Chen, Y. J. (2008). Intelligence vs. wisdom: The love of money, machiavellianism, and unethical behavior across college major and gender. Journal of Business Ethics, 82(1), 1-26. https://doi.org/10.1007/s10551-007-9559-1

54.Tang, Thomas Li Ping, Kim, J. K., \& Tang, D. S. H. (2000). Does attitude toward money moderate the relationship between intrinsic job satisfaction and voluntary turnover? Human Relations, 53(2), 213-245. https://doi.org/10.1177/a010560

55.Tang, Thomas Li Ping, Sutarso, T., Akande, A., Allen, M. W., Alzubaidi, A. S., Ansari, M. A., AriasGalicia, F., Borg, M. G., Canova, L., Charles-Pauvers, B., Cheng, B. S., Chiu, R. K., Du, L., Garber, I., De La Torre, C. G., Higgs, R. C., Safwat Ibrahim, A. H., Jen, C. K., Kazem, A. M., ... Vlerick, P. (2006). The Love of Money and Pay Level Satisfaction: Measurement and Functional Equivalence in 29 Geopolitical Entities around the World. Management and Organization Review, 2(3), 423-452. https://doi.org/10.1111/j.1740-8784.2006.00051.x

56.Triantoro, H. D., Utami, I., \& Joseph, C. (2020). Whistleblowing system, Machiavellian personality, fraud intention: An experimental study. Journal of Financial Crime, 27(1), 202-216. https://doi.org/10.1108/JFC-01-2019-0003

57.Trisnaningsih, S. (2007). Independensi auditor dan komitmen organisasi sebagai mediasi pengaruh pemahaman good governance, gaya kepemimpinan dan budaya organisasi terhadap kinerja auditor. Simposium Nasional Akuntansi X, 1-56.

58.Tunggal, A. W. (2013). The Fraud Audit: Mencegah dan Mendeteksi Kecurangan Akuntansi. Harvarindo.

59.Desa, Pub. L. No. 6 (2014). https://www.dpr.go.id/dokjdih/document/uu/UU_2014_6.pdf

60.Vaughan, F. (2002). What is Spiritual Intelligence? Journal of Humanistic Psychology, 42(2), 16-33. https://doi.org/10.1177/0022167802422003

61.Vitell, Scott J., Paolillo, J. G. P., \& Singh, J. J. (2006). The role of money and religiosity in determining consumers' ethical beliefs. Journal of Business Ethics, 64(2), 117-124.

https://doi.org/10.1007/s10551-005-1901-x

62.Vitell, Scott John, Singh, J. J., \& Paolillo, J. G. P. (2007). Consumers' ethical beliefs: The roles of money, religiosity and attitude toward business. Journal of Business Ethics, 73(4), 369-379. https://doi.org/10.1007/s10551-006-9212-4

63.Wolfe, D. T., \& Hermanson, D. R. (2004). The Fraud Diamond: Considering the Four Elements of Fraud. The CPA Journal, 74(12), 38-42.

https://www.proquest.com/openview/92c1d0cc15ea37e58fdf5ec4ebc3e636/1?pqorigsite $=$ gscholar $\& \mathrm{cbl}=41798$

64.Yuniar, G., Handayati, P., \& Putri, S. F. (2020). Integrity Issue on Grab Drivers' Fraud Phenomenon. International Journal of Accounting \& Finance in Asia Pasific, 3(2), 97-103. https://doi.org/10.32535/ijafap.v3i2.839

65.Zelmiyanti, R., \& Anita, L. (2015). Pengaruh Budaya Organisasi dan Peran Auditor Internal Terhadap Pencagahan Kecurangan dengan Pelaksanaan Sistem Pengendalian Internal Sebagai Variabel Intervening. Jurnal Akuntansi Keuangan Dan Bisnis, 8, 67-76.

66.Zhou, W., \& Kapoor, G. (2011). Detecting evolutionary financial statement fraud. Decision Support Systems, 50(3), 570-575. https://doi.org/10.1016/j.dss.2010.08.007

67.Zohar, D., \& Marshall, I. (2007). SQ-Kecerdasan spiritual (IX). Mizan Pustaka. 